\title{
GEOSTRATEGI INDONESIA MELALUI PENDEKATAN KESEJAHTERAAN DALAM KONSEPSI KETAHANAN NASIONAL DI BIDANG EKONOMI
}

\author{
Rizqi Amalia Setyaningrum ${ }^{(1)}$, Anita Trisiana ${ }^{(2)}$, Adityar Kirana ${ }^{(3)}$ \\ Universitas Slamet Riyadi
}

Email : rizqiamaliasetyaningrum@gmail.com, adityarkirana4@gmail.com

\begin{abstract}
ABSTRAK
Konsep ketahanan nasional merupakan pengetahuan dan pelaksanaan kesejahteraan serta keamanan secara seimbang, serasi dan selaras dalam segala aspek kehidupan bangsa. Pembangunan kesejahteraan diperlukan sebagai bagian dari pembangunan nasional. Karena, pembangunan kesejahteraan sangat memberikan peran untuk pencapaian pembangunan nasional, yaitu pertumbuhan ekonomi. Tujuan dari penelitian ini untuk menentukan pendekatan kesejahteraan dalam ketahanan nasional dibidang ekonomi. Untuk melakukan penelitian, digunakan metode kualitatif dan metode studi kasus. Terkait dengan penelitian ini, objek analisisnya adalah indikator metode kesejahteraan dan klasifikasi tertentu terhadap elastisitas nasional dalam sektor ekonomi sebagai geostrategi Indonesia. Hasil kajian ini menunjukan beberapa indikator penting terhadap ketahanan nasional melalui pendekatan kesejahteraan di bidang ekonomi ialah : (1) Indikator Pendapatan; (2) Indikator Pendidikan; (3) Indikator Kesehatan. Cara pandang kesehatan ekonomi rakyat sangat diperlukan demi peningkatan kesejahteraan ekonomi tersebut yang selama ini dianggap dapat memenuhi program penanggulangan kemiskinan yang hasilnya sampai sejauh ini masih kurang menyenangkan. Dalam hal itu sangat diperlukan adanya solusi masalah untuk semua golongan dan gotong- royong yang baik dari seluruh elemen masyarakat supaya tidak bergantung pada pemerintah dalam membantu kehidupan perekonomian masyarakat tersebut.
\end{abstract}

Kata Kunci : Ketahanan Nasional, Ekonomi, dan Kesejahteraan 


\begin{abstract}
The concept of national resilience is knowledge and implementation of welfare as well as balance, harmony and harmony in all aspects of national life. Welfare development is needed as part of national development. Because, welfare development greatly contributes to national development, namely economic growth. The purpose of this study is to determine the welfare approach in national economic resilience. To conduct research, using qualitative methods and case study methods. Related to this research, the object of analysis is the welfare criteria indicator and classifications of national elasticity in the economic sector as Indonesia's geostrategy. The results of this study indicate several important indicators of resilience through the welfare approach in the economic sector, namely: (1) Income indicators; (2) Educational indicators; (3) Health indicators. The perspective of people's economic health is very necessary for the improvement of economic welfare, which has been unable to fulfill poverty alleviation programs, whose results have so far been favorable. In this case, it is necessary to have a solution to the problem for all groups and good mutual coorperation from all elements of society who are responsible to the government in helping the economic life of the comumunity.
\end{abstract}

\title{
Keywords : National, Economic, and Welfare Resilience
}




\section{PENDAHULUAN}

Ketahanan nasional adalah keadaan negara dinamis, mencakup semua kehidupan negara serta menyeluruh, selain aspek-aspek kehidupan lainnya. Ketahanan nasional mempunyai ketangguhan untuk memperkuat Negara secara langsung dan tidak langsung dapat mengatasi berbagai permasalahan dan kegiatan yang membahayakan kedaulatan negara dari internal maupun eksternal untuk menjamin kelangsungan perekonomian nasional Indonesia dan Negara Kesatuan Republik Indonesia sesuai dengan Pancasila dan UndangUndang Dasar 1945. Ketahanan ekonomi tercemin dari keadaan kehidupan ekonomi negara, yang meliputi kemampuan memelihara stabilitas ekonomi yang sehat dan dinamis, serta kemampuan untuk mewujudkan kemandirian ekonomi nasional yang berdaya saing tinggi dan menciptakan kemampuan yang adil dalam menciptakan kemakmuran yang adil dan setara dengan rakyat. Oleh karena itu, pembangunan ekonomi dapat mencapai fleksibilitas ekonomi yang stabil dengan menciptakan perekonomian yang sehat dengan menggunakan iptek, ketersediaan sumber daya, melindungi fungsi lingkungan, dan menaikkan persaingan dalam lingkup global.

Ekonomi merupakan salah satu aspek yang terkait dengan memenuhi kebutuhan social masyarakat dalam kehidupan, termasuk produksi, distribusi, dan konsumsi produk dan layanan. Upaya harus dilakukan demi meningkatkan standar kehidupan seluruh orang dalam masyarakat, dan untuk meningkatkan metode pemenuhan kebutuhan kesejahteraan dalam kehidupan sosial. Untuk mewujudkan kesejahteraan warganya, negara memegang peranan penting dalam konsep nasional. Dalam hal ini pemerintah sedang melaksanakan perumusan kebijakan yang mempengaruhi setiap orang terkait perolehan penghasilan, keamanan dalam hal pendidikan serta layanan kesehatan.
Suatu negara yang sejahtera berperan penting dalam melindungi dan memprioritaskan ekonomi dan kesejahteraan sosial warganya, maka negara kesejahteraan adalah konsep pemerintah. Hal ini berdasar pada prinsip kesetaraan kesepakatan, pemerataan pendapatan, dan tanggung jawab sosial bagi mereka yang tidak mencapai kebutuhan minimum untuk penghidupan yang layak.

Pembangunan ekonomi merupakan salah satu kehidupan yang paling mendesak di luar negeri dan kehidupan bernegara, bagian penting untuk mendukung keuletan dan mencapai taraf hidup yang lebih baik dan metode pengamanan adalah kelulusan negara Indonesia untuk melindungi seluruh negeri. Bebas dari gangguan eksternal dan internal. Sebagaimana dikatakan Alinea IV dalam pembukaan UUD 1945, kedua cara ini pada hakikatnya adalah untuk memajukan kesejahteraan masyarakat.

Tujuan pembangunan ekonomi adalah untuk peningkatan pendapatan, memberikan peluang pendidikan yang seluas-luasnya, serta berupaya untuk meningkatkan layanan kesehatan yang adil, akan tetapi mengingat kondisi geografis dan keragaman etnis dan budaya yang besar, upaya untuk mencapai tujuan tersebut tidaklah mudah. Oleh karena itu, geostrategi Indonesia perlu diperhatikan, yaitu pemanfaatan kondisi geografis bukan merupakan halangan untuk mencapai tujuan tersebut, tetapi merupakan tantangan.

Perencanaan pembangunan harus didasarkan pada skala prioritas dan penggunaan sumber daya lain yang wajar. Dengan kata lain, kita harus secara efektif mempertimbangkan pemakaian sumber daya yang tersedia untuk keberhasilan tujuan pembangunan terbaik. Pencapaian tujuan yang dicanangkan merupakan faktor pendukung ketahanan ekonomi negara untuk kemakmuran semua orang, oleh sebab itu pentingnya pengkajian indikator kedaruratan terhadap 
kesejahteraan. Pada dasarnya, penelitian tersebut difokuskan untuk mengintegrasikan kebebasan ekonomi ke dalam sektor ekonomi geostrategi Indonesia melalui metode kesejahteraan.

\section{METODE}

Metode penelitian ini menggunakan metode kualitatif yaitu menganalisis dan deskriptif yang didasarkan oleh prinsip- prinsip yang berhubungan dengan kejadian masyarakat, oleh karena itu untuk memperoleh gambaran melalui objek diskusi dilakukan melalui metode perilaku masyarakat. Terkait dengan penelitian ini objek analisisnya adalah indikator metode kesejahteraan dan klasifikasi tertentu terhadap elastisitas nasional dalam sektor ekonomi sebagai geostrategi Indonesia. Jenis data yang dibutuhkan adalah : (1) Konsep ketahanan nasional yang dikemukakan oleh Lemhannas; (2) Epidemioligi geostrategi secara sistematis menjelaskan ilmu geostrategi. Data tersebut bersumber dari wawancara (data utama) dan dokumen ilmiah (data pelengkap) antara lain buku pedoman, metode undangan, buku referensi, hasil penelitian, artikel, dan media massa terkait.

\section{HASIL PEMBAHASAN}

\section{Prespektif Ketahanan Nasional Dalam Geostrategi Indonesia di Bidang Ekonomi}

Pembangunan nasional dicapai melalui strategi Indonesia yang disebut "geostrategi". Yaitu suatu metode pencapaian dengan menggunakan tujuan rencana yang telah ditetapkan. Untuk setiap negara di masa lalu, sekarang dan masa depan, geostrategi merupakan masalah penting.

Geostrategi sangat diperlukan sebab negara yang penuh menjadi negara membutuhkan strategi untuk menggunakan jangkauan nasional dalam ruang lingkup nasional dalam menentukan kebijakan, sarana dan tujuan pencapaian kepentingan dan cita-cita nasional lewat pembangunan dengan demikian, negara dapat terus berkembang di ideologi, politik, ekonomi, masyarakat, budaya dan HanKam.

Geostrategi diartikan sebagai cara atau aturan untuk mencapai cita-cita suatu bangsa dan tujuaan pembangunan, dengan memberi arahan untuk merumuskan metode dalam keputusan pembangunan yang terukur dapat dibayangkan demi mencapai kehidupan yang lebih baik, dan lebih bermartabat. Indonesia mengartikan geostratgi sebagai salah satu cara untuk mewujudkan deklarasi ideal yang tertuang pada pembukaan UUD 1945 dengan proses pembangunan nasional. Pernyataan pembukaan UUD 1945 menjadi dasar geostrategi Indonesia. Hal ini sesuai dengan status Pembukaan Undang-Undang Dasar 1945 di Indonesia. Pancasila adalah landasan negara, atau disebut "staatsfundamentalnom" dalam UndangUndang, atau subjek dari peraturan dasar nasional sebagai sumber hukum dasar negara.

Oleh karena itu geostrategi Indonesia adalah cara menggunakan seluruh konstelasi dalam menentukan kebijakan seluruh negara berdasarkan asas kemanusiaan dan keadilan sosial.

Perwujudan ketahanan ekonomi tercermin dari keadaan kehidupan negara yang dapat menjaga kestabilan perekonomian dalam rangka untuk menciptakan kemakmuran dan keadilan seluruh rakyat. Oleh karena itu, pembangunan ekonomi bertujuan untuk menjaga kelenturan perekonomian melalui suasana bisnis yang stabil dan penggunaan iptek, ketersediaan faktor produksi, dan peningkatan persaingan dalam ekonomi global.

Sistem ekonomi Indonesia yang bertujuan untuk mencapai kemakmuran dan kesejahteraan, menjamin kelangsungan hidup suatu bangsa dan negara melalui pembangunan ekonomi rakyat dan berdasarkan Undang-Undang Dasar 1945, sehingga menjamin keadilan di seluruh wilayah Indonesia. 
Mendistribusikan perekonomian serta merata dan memperkuat struktur perekonomian secara seimbang, saling menguntungkan, serasi dan terpadu. Integrasi antara pertanian, industri, dan industri jasa.

Negara kita adalah negara besar, secara geografis, demografis dan sebagai sumber kekayaan alam. Dari perspektif demografis, kita memiliki banyak orang terdidik, banyak di antaranya pandai berpartisipasi di berbagai sektor di dalam dan di luar negeri. Padahal dari segi geografisnya, yang mengaruh pada posisi yang sangat strategi di negara kita.

Begitu pula kita memiliki sumber daya alam yang melimpah, mulai dari sumber daya alam yang tidak terbarukan hingga sumber daya alam yang terbarukan. Pertanyaan yang sekarang muncul adalah bagaimana kita mengolah harta benda yang kita miliki untuk memaksimalkan penggunaannya untuk kepentingan bangsa dan negara. Tapi kenapa sekarang malah sebaliknya? Dengan kekayaan-kekayaan alam dan posisinya yang strategis, negara ini sebenarnya jauh lebih rendah dibandingkan negara tanpa sumber daya alam seperti Jepang dan Singapura.

Kegagalan mengenai meningkatnya angka kemiskinan dan pengangguran akan mengakibatkan penurunan ketahanan negara kita. Hal ini didasarkan pada asumsi bahwa kemiskinan dan pengangguran terkait dengan meningkatnya angka kejahatan. Jika kejahatan ini meningkat, maka negara tersebut akan terancam di dalam negeri, yang akan berdampak pada risiko lainnya. Dalam hal ini, setiap orang dapat melakukan apapun untuk menentukan beban hidup yang dideritanya. Oleh karena itu, jika kita ingin meningkatkan kemampuan pertahanan negara, tigas pemerintah adalah mewujudkan pemerataan pembangunan dan memakmurkan pembangunan rakyat.

Ketahanan nasional dibutuhkan sebagai penunjang keberhasilan peran serta tugas pemerintah untuk mewujudkan kesejahteraan dan kemakmuran suatu negara. Tujuan ketahanan nasional pada dasarnya adalah untuk menghadapi ancaman, tantangan, hambatan, dan gangguan (AGHT). Dengan demikian, yang dibutuhkan saat ini yaitu bagaimana membangun ketahanan nasional secara bottom-up dengan meningkatkan kemampuan adaptasi lingkungan, kemampuan adaptasi keluarga dan kemampuan adaptasi personal. Ketahanan nasional diharapkan dapat berkembang melalui pendekatan bottom-up, dan diharapkan kelangsungan hidup suatu bangsa dan Negara dapat terwujud.

Inilah ketahanan ekonomi, pada hakikatnya merupakan kehidupan ekonomi nasional yang didirikan berdasarkan UUD 1945 dan Pancasila, Filsafat Pancasila mengedepankan kesejateraan seluruh elemen masyarakat, kemampuan menjaga stabilitas perekonomian yang kondusif dan bersemangat, atau membangun persaingan yang tinggi. Pembangunan ekonomi yang kuat untuk pembangunan wilayah.

\section{Faktor Ketahanan Nasional di Bidang Ekonomi}

Sistem ekonomi yang dianut oleh suatu negara akan meningkatkan taraf hidup ekonomi negara yang bersangkutan.

Pembangunan ekonomi mencapai fleksibilitas ekonomi yang stabil dengan menciptakan lingkungan usaha yang stabil dan menggunakan iptek, penyediaan kebutuhan konsumen, dan meningkatkan persaingan global. Sebagai sistem ekonomi Bekerja bersama artinya setiap warga negara memiliki hak dan kewajiban yang sama dalam proses penyelenggaraan ekonomi dan pencapaian kesejahteraan nasional. Secara makro, sistem perekonomian Indonesia disebut Sistem Perekonomian Rakyat.

Kehidupan bangsa yang komprehensif, termasuk ketahanan sebagai kemampuan untuk meningkatkan kekuatan negara, yang dapat menangani dan mengatasi semua masalah serta kegiatan 
yang membahayakan kedaulatan negara dari internal dan eksternal (interferensi). Ketahanan negara dalam ekonomi dapat direfleksikan dalam berbagai situasi, di mana kehidupan perekonomian nasional negara ini bisa mempertahankan kemerdekaan ekonomi Nasional

Untuk mencapai ketahanan nasional yang diharapkan, diperlukan banyak faktor, seperti :

- Perekonomian rakyat harus menghindari

liberalisme, nasionalisme, dan sistem monopoli.

- Pembangunan ekonomi mendorong dan memotivasi partisipasi aktif masyarakat.

- Pengembangan antar departemen dan wilayah.

- Dalam keterpaduan antara pertanian industri dan industri jasa, struktur ekonomi diperkuat secara seimbang dan saling menguntungkan, dsb.

Di bidang ketahanan nasional Perekonomian juga meningkat pesat permasalahan dari berbagai kelompok masyarakat. Misalnya, kenaikan harga BBM dirilis pada 23 Mei 2008. Masyarakat semakin sulit untuk memilih ini dan demonstrasi telah diadakan. Yang paling terpengaruh oleh naiknya harga Bahan Bakar Minyak yaitu golongan bawah sebab terpenuhinya kebutuhan mereka sehari-hari lebih sulit. Perekonomian merupakan semuanya yang melekat pada usaha manusia dalam bertahan hidup dan keberlangsungan hidup suatu Negara. Apabila perekonomian suatu negara baik, maka bisa dikatakan negara tersebut adalah negara maju, karena kegiatan produksinya yang melibatkan tenaga kerja modal, tehnologi, SDA dan menajemen juga baik.

Dalam ketahanan nasional, perekonomian sangat penting, sebab perekonomian yang stabil berdampak positif pada ketahanan nasional suatu negara. Ekonomi adalah Aspek yang terkait implementasi kebutuhan sosial dalam hidup Masyarakat, termasuk produksi, penjualan, dan konsumsi produk dan layanan. Upaya peningkatan taraf hidup individual tau kelompok dalam masyarakat, dan perbaikan metode pemenuhan kebutuhan dalam kehidupan bermasyarakat. Oleh karena itu, aspek ekonomi memiliki pengaruh penting yang besar karena berhubungan masyarakat secara langsung. Contohnya ketahanan nasional di ketahanan pangan. Tentunya dengan perekonomian yang stabil, Negara tersebut dapat memenuhi kebutuhan pangan warganya tanpa kesulitan.

Apabila perekonomian suatu negara sedang baik, aspek lain yang juga akan terpengaruh adalah pendidikan. Gaji tenaga pengajar sesuai akan berakibat kinerjanya semakin baik yang bermuara pada kenaikan pendidikan di Indonesia. Tingkat kecerdasan penduduk di suatu negara memiliki sumber daya manusia yang meningkat, tentunya ketahanan nasional juga sangat kuat. Lapangan kerja menjadi meningkat dan pengangguran akan berkurang.

Pertahanan nasional juga merupakan aspek sama pentingnya, sejauh menyangkut ketahanan negara. Bagi negara di belahan dunia sangat penting karena banyak menyerap pengeluaran belanja negara. Misalnya, membeli alutsista (alat utama sistem senjata Tentara Nasional Negara) merupakan salah satu cara untuk mempertahankan pertahanan negaranya. Indonesia adalah negara kepulauan dan begitu mudah terkena terhadap serangan yang mengancam keutuhan Negara Kesatuan Republik Indonesia. Oleh sebab itu, dibutuhkan Angkatan Pertahanan Nasional yaitu TNI. TNI sebagai pionir untuk mencegah terjadinya gangguan dari luar. Dengan demikian, untuk mencapai tujuan tersebut diperlukan perekonomian yang kuat dan stabil.

\section{Pendekatan Kesejahteraan}

Menurut Undang-Undang tentang Kesejahteraan, kesejahteraan yaitu tatanan kehidupan, kehidupan sosial, material, dan 
spiritual yang diselimuti oleh rasa aman, akhlak, dan kedamaian lahir dan batin, yang memungkinkan setiap warga negara untuk melakukan yang terbaik untuk memenuhi kebutuhan-kebutuhan fisik, mental, dan sosial. Dengan mentaati hak asasi dan kewajiban manusia sesuai dengan Pancasila baik bagi diri sendiri, keluarga dan masyarakat.

Kesejahteraan merupakan aspek utama dalam melindungi serta memajukan kestabilan ekonomi dan sosial, dengan keadaan tersebut, maka perlu diminimalkan dalam mengurangi adanya perbedaan dalam kehidupan bermasyarakat. Oleh karena itu, setiap orang membutuhkan kondisi untuk sejahtera, baik kesejahteraan materiil maupun kemakmuran non materiil, agar tercipta suasana yang harmonis dalam masyarakat.

Kesejahteraan sosial mengacu pada status keseluruhan dari nilai guna sosial. Kesejahteraan bisa diukur dengan jumlah dasar dollar AS (rupee) atau jumlah nominal nilai guna relatif. Karena masalah umum yang membuat keakuratan metode ini meragukan, metode ini jarang digunakan saat ini. Ekonomi kesejahteraan memiliki dua aspek yaitu eifisiensi ekonomi dan distribusi pendapatan.

Ada faktor utama untuk menggambarkan serta mengartikan kesejahteraan yaitu mengenai pendapatan, pendidikan, dan kesejahteraan. Dari beberapa faktor itu sangat berhubungan terhadap penerapan rancangan mengenai negara kesejahteraan yang terwujud dalam konteks sistem ekonomi dan sosial. Sehingga, negara kesejahteraan bukan hanya sebagai alat untuk mencapai kesejahteraan dari sisi ekonomi melainkan juga dari sisi layanan sosial. Oleh karena itu, pengertian negara kesejahteraan tidak hanya berdasarkan pada konsep normatif, tetapi juga metode sistematis yang ideal untuk menekankan fenomena di masyarakat bukan hanya ekonomi, tetapi setiap orang harus memiliki akses terhadap layanan sosial mengenai pendidikan dan kesehatan.

\section{Indikator Pendapatan}

Dari sisi produk nasional bruto dan produk domestik bruto, pendapatan per kapita sebagai salah satu parameter ekonomi makro jangka panjang yang dipakai dalam memperkirakan kemampuan dari suatu perekonomian. Pendapatan per kapita tampaknya sudah menjadi indikator makro ekonomi esensial, meskipun memiliki beberapa kekurangan. Oleh karena itu, peningkatan pendapatan nasional dibuat sebagai tolak ukur untuk pembangunan negara didunia ketiga. Tampaknya ada tanggapan bahwa peningkatan pendapatan nasional (pertumbuhan ekonomi) secara otomatis menunjukkan kesejahteraan dan kemakmuran masyarakat. Namun sebagian ahli berpendapat bahwa dengan menggunakan indikator ini, distribusi pendapatan nasional diabaikan. Indikator ini tidak mengukur pemerataan pendapatan dan kesejahteraan, termasuk akses yang sama ke sumber daya ekonomi.

Tingkatan pendapatan sangat berhubungan kaitannya mengenai kemiskinan dan lapangan kerja. Pada dasarnya seseorang yang tergolong miskin mayoritas pengangguran atau kerja dengan upah minimum, oleh sebab itu tidak mampu mencukupi kebutuhan sehari-hari, seperti kebutuhan pokok, kebutuhan pendukung dan kebutuhan barang mewah. Tetapi ada beberapa kejadian seseorang yang pengangguran namun mendapatkan uang dengan teratur sebab menerima penghasilan dalam bentuk warisan atau investasi.

Standar tingkat penghasilan digunakan untuk mencapai kesejahteraan, dan negara memiliki pertanggungjawaban dalam mengesahkan Peraturan Perundang Undangan untuk menerapkan standar tersebut dalam bentuk kebijakan. Pasal 27 dan Pasal 33 UUD 1945 mengatur tentang kebijakan pemerintah untuk meningkatkan pendapatan warga negara. Dalam Pasal 27 
ayat (2) berbunyi "Tiap warga negara berhak atas pekerjaan dan penghidupan yang layak bagi kemanusiaan.”.

Pada intinya, pendapatan yang diperoleh seseorang atau badan usaha akan dipengaruhi oleh banyak faktor, seperti tingkat pendidikan dan pengalaman seseorang, semakin tinggi tingkat pendidikan dan pengalaman, semakin tinggi tingkat pendapatan, dan tingkat pendapatan tersebut juga tunduk pada mobilitas. Dana, jam kerja dan akses kredit sangat terpengaruh. Tergantung pada jumlah pekerja di rumah tangga, komoditas, produk dan faktor lain.

\section{Indikator Pendidikan}

Indikator pendidikan adalah ketrampilan dasar khusus yang dapat digunakan sebagai gelar untuk memungkinkan siswa menguasai suatu topik tertentu. Berkaitan dengan pengembangan indikator perlu diperhatikan tujuan ketrampilan itu dapat dilihat melalui kata kerja yang dipakai pada keterampilan dasar tujuan siswa, karakteristik sekolah, kemampuan, dan kebutuhan siswa, masyarakat, lingkunga atau wilayah.

Tujuan indikator untuk mengontrol keefektifan pendidik dalam menyelenggarakan pendidikan. Indikator pendidikan merupakan indikator kuantitas dan kualitas pendidikan dan merupakan alat evaluasi peserta didik dalam sistem pendidikan. Namun harus diakui juga bahwa dalam beberapa kasus, walaupun tingkat pendidikannya tidak terlalu tinggi, ia tetap bisa meraih kesuksesan melalui usaha dan kerja yang sesuai merupakan aset jangka panjang yang mendukung pembangunan ekonomi yang berkelanjutan yang ditargetkan. Pendidikan merupakan upaya mencerdaskan bangsa agar setiap warga negara Indonesia mempunyai kemampuan dan kapabilitas yang bisa meningkatkan kualitas kerjanya. Mempunyai daya saing yang lebih dalam menghadapi persaingan global. Dengan demikian, sebagai pelaksana konsep negara kesejahteraan, pemerintah melaksanakan berbagai kebijakan, seperti memperoleh dana pendidikan dan pendidikan yang terjangkau, penyedia SDM (tenaga pengajar), yang tepat dan berkeadilan, dan kursus pendidikan yang berbasis kemampuan serta fasilitas dan yayasan pendidikan lainnya. Fasilitas penunjang, fasilitas moral dan fisik (gedung dan fasilitas fisik lainnya).

Tanpa memiliki SDM yang berkualitas, SDA yang melimpah serta modal dan sumber daya teknologi yang lebih kompleks tidak akan memberikan nilai tambah. Jadi peningkatan kualitas suatu negara didasarkan pada peningkatan kualitas sumber daya manusia, dan itu hanya dapat dicapai dengan mengedepankan pentingnya pendidikan. Artinya, pendidikan talah memberikan pengaruh yang penting bagi peningkatan kualitas bangsa, dan tentunya juga berlaku untuk Indonesia. Untuk meningkatkan peran pendidikan dalam meningkatkan kualitas negara, semua pihak (pendidikan itu sendiri, sektor swasta, pemerintah, dan manajemen masyarakat yang luas) telah memberikan kontribusi penting. Dalam pengelolaan pendidikan, industri pendidikan harus dipandang sebagai industri yang bermartabat yang perlu dijalankan secara profesional, terfokus pada kualitas pendidikan itu sendiri, terutama menciptakan harkat dan martabat bangsa. Disisi lain, pemerintah harus melakukan upaya serius untuk meningkatkan kualitas pendidikan dan masyarakat harus sadar akan kontribusi pendidika untuk kesejahteraan dan pembagunan masa depan negeri ini untuk menjadi negara yang maju. Disepakati bahwa indikator pendidikan berperan sebagai proksi, peringatan awal dan evaluasi kebijakan Kemendikbud berdasarkan pemahaman para pengambil kebijakan pendidikan sebagai standar untuk mengukur kemajuan sebuah pembangunan pendidikan.

\section{Indikator Kesehatan}

Sebagai salah satu unsur kesejahteraan universal, kesehatan harus 
dicapai melalui pembangunan nasional yang berkelanjutan berdasarkan Pancasila dan UUD 1945. Sistem Kesehatan Nasional (SKN) merupakan salah satu bentuk implementasi. Secara sinergis, efektif, dan efisien, memanfaatkan segala potensi negara, pemerintah, swasta, dan masyarakat untuk melaksanakan pembangunan yang sehat guna mencapai derajat kesehatan masyarakat yang setinggi-tingginya. Pembangunan kesehatan bertujuan untuk meningkatkan kesadaran, kemauan, dan kemampuan semua orang, sehingga semua orang dapat hidup sehat dan mencapai derajat kesehatan masyarakat yang setinggitingginya. Dilaksanakan secara bersamasama oleh pemerintah, swasta, dan masyarakat. Dinamika kehidupan berbangsa dan bernegara seperti inilah yang tertuang dalam kesehatan nasional. Dalam sistem kesehatan nasional, seluruh peran aktif masyarakat, termasuk swasta harus dibimbing bisa dapat menjalankan perannya sebagai pemerintah. Fungsi sosial dan tanggung jawab pemerintah mitra. Peranan pemerintah difokuskan pada pengawasan serta pemantuan demi mencapai kondisi yang serasi dan seimbang antara pemerintah dengan upaya kesehatan masyarakat, termasuk swasta.

Kesehatan merupakan hak semua masyarakat Indonesia, dan masyarakat berhak mendapatkan fasilitas kesehatan yang layak. Apabila produktivitas pekerja dengan kesehatan yang buruk akan menyebabkan juga pertumbuhan ekonomi menurun. Oleh karena itu, perawatan kesehatan yang lebih baik akan meningkatkan pendapatan per kapita, dan meningkatkan pertumbuhan ekonomi negara.

Dengan indikator memiliki dimensi yang lebih luas dan lebih menjelaskan dari berbagai aspek ekonomi, pendidikan dan kesehatan. Dari indikator tersebut adanya hubungan mengenai negara kesejahteraan, yang menerangkan tentang pentingnya peranan pemerintah dalam memakmurkan masyarakatnya dengan menyediakan fasilitas dan layanan yang sesuai. Fungsinya supaya informasi lebih banyak mengalir. Pendapatan, pendidikan, dan kesehatan mudah dijangkau (Suryono, 2014) untuk mencapai tingkat kesejahteraan yang adil dan berkeadilan.

Rekomendasi yang dibuat melalui penelitian yaitu :

\section{1) Perlu meningkatkan efisiensi kerja melalui sistem penghargaan}

Jika target produksi terlampui, upah atau bonus / tunjangan tambahan diberikan. Hal ini memberikan insentif bagi pekerja untuk bekerja lebih keras guna peningkatan kesejahteraan.

2) Pelatihan dan ketrampilan kerja perlu terus ditingkatkan melalui partispasi dari unit atau komunitas human office atau regional office

Kebijakan tersebut bertujuan untuk melengkapi pendidikan formal guna meningkatkan kualitas dan tingkat profesional tenaga kerja sehingga mereka dapat memperoleh penghasilan yang lebih untuk menjaga kesejahteraannya.

\section{3) Pengawasan langsung dan berkelanjutan diperlukan ketika sektor kesehatan melaksanakan kebijakan pemerintah}

Hal tersebut perlu dipantu secara terarah dan berkesinambungan guna mencapai tujuan pembangunan yang sehat dan peningkatan kesejahteraan secara adil dan setara.

\section{SIMPULAN}

Ketahanan ekonomi merupakan dinamika kehidupan ekonomi suatu bangsa, yang meliputi ketahanan dan keuletan yang mempunyai kemampuan untuk mengembangkan ketahanan nasional dalam mengatasi ancaman, hambatan, gangguan, dan tantangan baik yang bersifat langsung maupun tak langsung dari luar negeri dan dalam negeri demi 
perekonomian suatu negara. Pembangunan ekonomi merupakan cara menstabilkan ketahanan ekonomi dengan lingkungan usaha yang stabil, pemanfaatan iptek, ketersediaan barang dan jasa, serta peningkatan daya saing dalam lingkup persaingan ekonomi global. Dua rencana ekonomi prioritas yang dirumuskan dalam Rencana Kerja Pemerintah (RKP) 2020, antara lain :

(a) Rencana Infrastruktur dan Ekuitas Wilayah : 1) Peningkatan pelayanan dasar dan infrastruktur perekonomian guna peningkatan perlindungan terhadap komunitas dari kerentanan dan risiko tinggi; 2) infrastruktur ekonomi guna memastikan proses produksi dan distribusi demi ketahanan sektor UMKM dan ekonomi informal; 3) Daerah yang bertujuan untuk meluaskan

cakupan jaminan sosial, peningkatan pelayanan dasar berkualitas tinggi, dan meningkatkan inklusi keuangan yang adil. (b) mengembangkan pembangunan ekonomi yang memiliki nilai tambah, industrialisasi dan perluasan kesempatan kerja di seluruh negeri dan global secara luas.

Berbagai upaya harus dilakukan untuk peningkatan taraf hidup pribadi atau kelompok dalam masyarakat, dan untuk meningkatkan metode pemenuhan kebutuhan kesejahteraan dalam kehidupan sosial. Untuk mewujudkan kesejahteraan warganya, negara memegang peranan penting dalam hal negara sejahtera. Dalam hal ini pemerintah sedang merumuskan kebijakan yang memepengaruhi setiap orang terkait perolehan penghasilan, keamanan dalam hal pendidikan serta layanan kesehatan.

Tujuan pembangunan ekonomi adalah untuk peningkatan pendapatan, memberikan peluang pendidikan yang seluas-luasnya, serta berupaya untuk meningkatkan layanan kesehatan yang adil, akan tetapi mengingat kondisi geografis dan keragaman etnis dan budaya yang besar, upaya untuk mencapai tujuan tersebut tidaklah mudah. Oleh karena itu, geostrategi Inodonesia perlu diperhatikan, yaitu pemanfaatan kondisi geografis bukan merupakan halangan untuk mencapai tujuan, tetapi merupakan tantangan.

Pembangunan nasional dicapai melalui strategi Indonesia yang disebut "geostrategi" yaitu suatu metode pencapaian tujuan sesuai dengan rencana yang telah ditetapkan. Untuk setiap negara di masa lalu, sekarang dan masa depan.

Kesejahteraan merupakan peranan yang sangat penting dalam memajukan di bidang sosial dan ekonomi, dengan demikian, maka perlu diminimalkan demi mengurangi kecemburuan sosial di masyarakat. Oleh karena itu, setiap orang membutuhkan kondsi untuk sejahtera.

Ada faktor utama untuk menggambarkan serta mengartikan kesejahteraan yaitu mengenai pendapatan, pendidikan, dan kesehatan. Dari beberapa faktor itu sangat berhubungan terhadap penerapan rancangan mengenai negara kesejahteraan yang terwujud dalam konteks sistem ekonomi dan sosial.

Sehingga, negara kesejahteraan bukan hanya sebagai alat untuk mencapai kesejahteraan dari sisi eknomi melainkan juga dari sisi layanan sosial. Oleh karena itu, pengertian negara kesejahteraan tidak hanya berdasarkan konsep normatif, tetapi juga meode sistematis yang ideal untuk menekankan fenomena di masyarakat bukan hanya ekonomi, tetapi setiap orang harus memiliki akses terhadap layanan sosial mengenai pendidikan dan kesehatan

Kehidupan bangsa yang komprehensif, termasuk ketahanan sebagai kemampuan untuk meningkatkan kekuatan negara, yang dapat menangani dan mengatasi semua masalah seta kegiatan yang membahayakan kedaulatan negara dari internal dan eksternal (interferensi). 


\section{DAFTAR PUSTAKA}

Holligans, Smart. (2011).

"Ketahanan Nasional Berdasarkan

Pendekatan Kesejahteraan (Prosperity

Approach) dann Pendekatan

Keamanan (Security Approach)".

http://smartholligans1932.blogspot.com/

20/11/12/normal-0-false-false-in-X-non-

$\underline{\mathrm{x} . h t m l ? \mathrm{~m}=1}$

Suradi. (2012). "Pertumbuhan Ekonomi dan Kesejahteraan Sosial”. https://media.neliti.com/media/public ati ons/52806-ID-pertumbuhanekonomi- dan-kesejahteraan-so.pdf

Amanda, Icha. (2020). "Pembangunan Perekonomian di Indonesia selaku Negara Berkembang". https://yoursay.suara.com/news/2020/1 0/16/123245/pembangunanperekonomian -di-indonesia-selakunegaraberkembang?page $=$ all

Lestari, Siti. (2017). "Makalah Geostrategi Indonesia”. http://kumpulanmakalah123.blogspot.c om/2017/07/makalahgeostrategiindonesia.html

Pertiwi, Pitma. (2015). "Analisis Faktorfaktor Yang Mempengaruhi Pendapatan Tenaga Kerja di Daerah Istimewa Yogyakarta:”. https://eprints.uny.ac.id/21513/1/SKRI PSIPITMA\%20PERTIWI_11404241038 .pdf

Muhardi. (2004). “Kontribusi Pendidikan Dalam Meningkatkan Kualitas Bangsa Indonesia".

https://media.neliti.com/media/publica ti ons/156226-ID-kontribusipendidikan- dalam-meningkatkan.pdf

Siska, Efliana. (2015). "Ketahanan Nasional (Bidang Ekonomi) Softskill". http://eflianisiska02.blogspot.com/?m= $\underline{1}$ 